\title{
Ultramafic rocks in the North Patagonian Andes: is their emplacement associated with the Neogene tectonics of the Liquiñe-Ofqui Fault Zone?
}

\author{
Francisco Hervé ${ }^{1,2}$, Francisco Fuentes ${ }^{1}$, Mauricio Calderón', Mark Fanning ${ }^{3}$, \\ Paulo Quezada ${ }^{1,6}$, Robert Pankhurst ${ }^{4}$, Carlos Rapela ${ }^{5}$
}

\author{
I Carrera de Geología, Universidad Andrés Bello, Sazié 2119, Santiago, Chile. \\ fherve@unab.cl;ffuentes@unab.cl;m.calderon@unab.cl \\ 2 Departamento de Geología, Universidad de Chile, Plaza Ercilla 803, Santiago, Chile. \\ fherve@cec.uchile.cl \\ 3 Research School of Earth Sciences, The Australian National University, Canberra, ACT 0200, Australia. \\ mark.fanning@anu.edu.au \\ 4 Visiting Research Associate, British Geological Survey, Keyworth, Nottingham NG12 5GG, United Kingdom. \\ rjpankhurst@gmail.com \\ 5 Centro de Investigaciones Geológicas, Universidad Nacional de la Plata, Diagonal 113, No. 275, 1900 La Plata, Argentina. \\ crapela@cig.museo.unlp.edu.ar \\ ${ }_{6}^{6}$ Seremi de Minería Región de Aysén, Ministerio de Minería, Baquedano 336, Coyhaique, Chile. \\ pquezada@minmineria.cl
}

\begin{abstract}
Serpentinites and fresh or partially serpentinized harzburgite crop out in the western slope of the North Patagonian Andes of continental Chiloé $\left(41^{\circ} 44^{\prime}-42^{\circ} 12^{\prime}\right.$ S). These rocks are spatially associated with low-grade metamorphic rocks containing Cenozoic detrital zircons. The metamorphic rocks, together with Devonian metasediments, have been mapped previously as Late Paleozoic-Triassic metamorfic complex, an age no longer tenable for at least part of the complex. Transpressional tectonic emplacement of the ultramafic body or bodies is thought to have been related to activity on the Liquiñe-Ofqui Fault Zone, following a late Oligocene-Early Miocene extensional phase in the forearc region of the present Andes. This fault zone occurs immediately east of the outcrops of the ultramafic rocks and has been interpreted previously as generating a hemi-flower or flower structure.
\end{abstract}

Keywords: Serpentinites, North Patagonian Andes, Liquiñe-Ofqui Fault Zone, Neogene tectonics.

RESUMEN. Rocas ultramáficas en los Andes norpatagónicos: ¿está su emplazamiento asociado a la actividad tectónica Neógena de la Zona de Falla Liquiñe-Ofqui? En la vertiente occidental de los Andes norpatagonicos de Chiloé continental $\left(41^{\circ} 44^{\prime}-42^{\circ} 12^{\prime} \mathrm{S}\right)$ afloran serpentinitas y harzburgitas frescas o parcialmente serpentinizadas. Estas rocas están espacialmente asociadas con rocas metamórficas de bajo grado que contienen circones detríticos Cenozoicos. Estas rocas metamórficas, junto a metasedimentos Devónicos, han sido mapeados previamente como del Paleozoico superior-Triásico, una edad que no es sostenible para al menos una parte de ellos. El emplazamiento tectónico transpresivo del o de los cuerpos ultramáficos, se supone relacionado a la actividad de la Zona de Fallas Liquiñe-Ofqui, después de una fase extensional del Oligoceno tardío-Mioceno temprano en la región de antearco de los Andes actuales. La mencionada zona de fallas aparece inmediatamente al este de los afloramientos de rocas ultramáficas, y ha sido previamente interpretada como causante de una estructura de flor o hemiflor. 


\section{Introduction}

Ongoing research in the western foothills of the North Patagonian Andes between latitudes $41^{\circ} \mathrm{S}$ and $43^{\circ} \mathrm{S}$ (Fig. 1) has included the study of previously little-known ultramafic rock bodies that crop out in the area. This portion of the Andean Main Range is locally named Continental Chiloé, as it is at the same latitude as Chiloé island which forms part of the Coast Range to the west and from which it is separated by marine invasion of the Longitudinal Depression. The existence of ultramafic rocks at
Río Velásquez in northern Peninsula Huequi was mentioned by Muñoz-Cristi $(1931)^{1}$, who stated that they cut across volcanic and sedimentary formations. Subsequently they were referred to by Hervé et al. (1978) and Pankhurst et al. (1992) but without further information. Pérez (1999), Crignola (1999) and later Caro (2006) gave more detailed accounts of the lithology, distribution and geochemistry of the ultramafic rocks, in the latter case obtained during gold prospecting activities in the area. The geological evolution here has been relatively less studied than other regions, mainly due to the lack

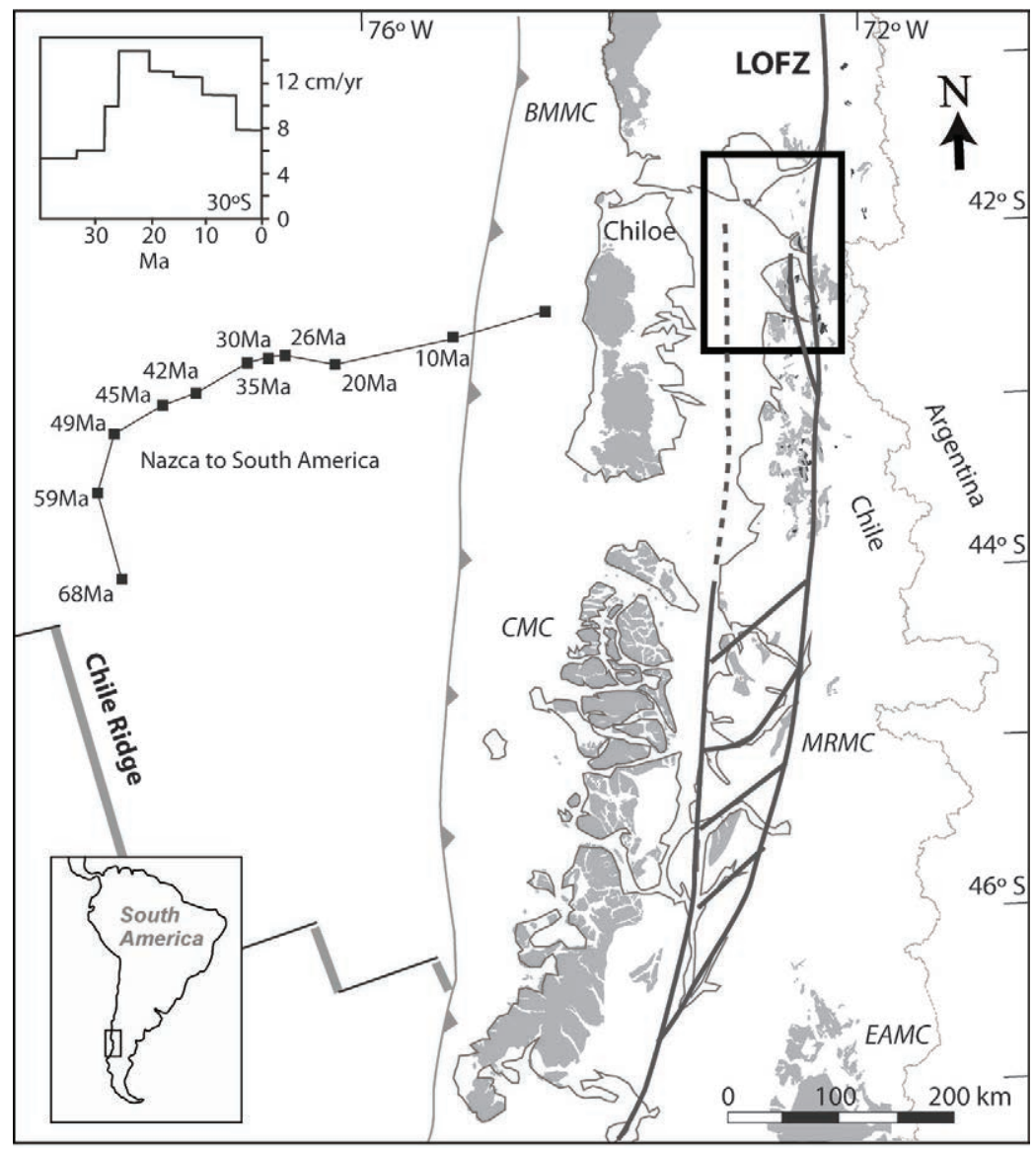

FIG. 1. Geological sketch map of the studied area, after Encinas et al. (2013), with the study area outlined by the rectangle. Outcrop areas of supposed basement rocks are shaded. Acronyms refer to: BMMC (Bahía Mansa metamorphic complex), CMC (Chonos metamorphic complex), MRMC (Main Range metamorphic complex) and EAMC (Eastern Andes metamorphic complex). The main faults in the Liquiñe-Ofqui fault zone (LOFZ) are indicated, as well as the position of a point in the Nazca plate relative to the continent through Cenozoic time (relative approach velocity shown in the the top left-hand graphic), after Cande and Leslie (1986).

\footnotetext{
${ }^{1}$ Muñoz-Cristi, J. 1931. Informe preliminar sobre los yacimientos platiníferos de Comau, Provincia de Chiloé. (Unpublished report), Departamento de Minas y Petróleo, Santiago, Chile: 9 p.
} 
of continuous roads from the adjacent areas of the mainland, so that access is mainly from the sea; forest cover is also very dense.

Outcrops of ultramafic rocks are scarce in the Chilean Andes. Heavily serpentinized ultramafic bodies occur sparsely in the Western Series of the paleo-accretionary wedge represented by the Coast Range metamorphic complexes of south-central Chile (Vergara, 1970; Ojeda, 1976; Alfaro, 1980; Hervé, 1988; Godoy and Kato, 1990; Crignola et al., 1997; Duhart et al., 2001). They have been considered as emplaced in a Late Paleozoic supra-subduction zone environment (Barra et al., 1998; Höfer et al., 2001; González-Jiménez et al., 2014). Peridotites form part of a banded layered mafic intrusion, mainly composed of troctolites and gabbro, in the Pennsylvanian Coastal Batholith of Central Chile (Hervé and del Campo, 1975; Hernández, 2006). Another significant occurrence of ultramafic rocks is in the Neogene Taitao ophiolite immediately south of the Chile triple junction, considered to have been emplaced by obduction related to collision of the Chile Ridge with the continental margin (Forsythe and Nelson, 1985; Anma et al., 2006). Ultramafic rock mantle xenoliths are known from Neogene volcanic rocks in the Patagonian Andes and in extra-Andean Patagonia (Schilling et al., 2008), giving an indication of the present composition of the mantle below Patagonia.

We have studied ultramafic rocks at Peninsula Huequi, at Pichicolo and at Caleta Puelche (Fig. 2). These dispersed outcrops are considered here to be part of the same geological unit, whose full extension in the area is not known. The outcrop area in the northern part of Peninsula Huequi was mapped as a Paleozoic-Triassic metamorphic complex (Crignola, 1999), and the ultramafic rocks have been considered to be in fault contact with Devonian intrusive rocks at Pichicolo (Duhart, 2008).

Neither the age nor the emplacement mode of the Huequi-Pichicolo-Caleta Puelche ultramafic unit is known. We present new information on the petrology, age and geological relationships of associated rock units. We present four $\mathrm{U}-\mathrm{Pb}$ detrital zircon age patterns and four igneous $\mathrm{U}-\mathrm{Pb}$ zircon crystallization ages for rock units spatially associated with the ultramafic rocks (in some places in direct contact); these allow some constraints on the possible emplacement ages of the latter. Two of the detrital zircon samples are from rocks previously mapped as a part of the supposedly Late Paleozoic Llancahue epi-metamorphic complex (Cembrano, 1990), one is from the Early Devonian (Fortey et al., 1992) Buill slates and one from the Miocene Ayacara Formation (Levi et al., 1966; Rojas, 2003; Encinas et al., 2013).

\section{Regional geological setting}

The Continental Chiloé segment of the Andes has a protracted evolution since at least Devonian times. At present, the area faces subduction of the Nazca plate, with the Chile triple junction being located $300 \mathrm{~km}$ to the southwest. A metamorphic complex, which has been correlated (Cembrano, 1990; Pankhurst et al., 1992) with the late Paleozoic accretionary complex of the coastal cordillera (e.g., Hervé, 1988) forms a major part of the outcrops. The Mesozoic geology is dominated by the North Patagonian Batholith (Pankhurst et al., 1992; Sernageomin, 2003; Pankhurst et al., 1999), formed as a result of subduction beneath the continental margin. The area then experienced generalized extension during the late Oligocene-early Miocene (Encinas et al., 2015), which allowed the deposition of deep water sediments due to marine incursions from both Pacific and Atlantic oceans (Encinas et al., 2014). Extension was followed by shortening when subduction became more orthogonal to the margin during the late Miocene, the extensional basins were inverted and the Liquiñe-Ofqui Fault Zone (LOFZ), a major right lateral wrench fault extending for more than $1,000 \mathrm{~km}$ in the North Patagonian Andes, formed in a transpressional regime (Hervé, 1976; Cembrano et al., 1996). The modern chain of supra-subduction zone volcanoes outlasted the glacial period during which the study area was entirely covered by ice (Heusser, 1990). Intense uplift and erosion during the late Miocene contractional episode (Adriasola et al., 2005) exposed the plutonic rocks of the North Patagonian Batholith along the trace of the LOFZ.

\section{Local geology}

The oldest well-dated rocks in the region are the Buill slate boulders (Fig. 2), in which Levi et al. (1966) and later Fortey et al. (1992) found Devonian trilobites; such fossils are extremely scarce in Chile. Mainly foliated low-grade metamorphic 


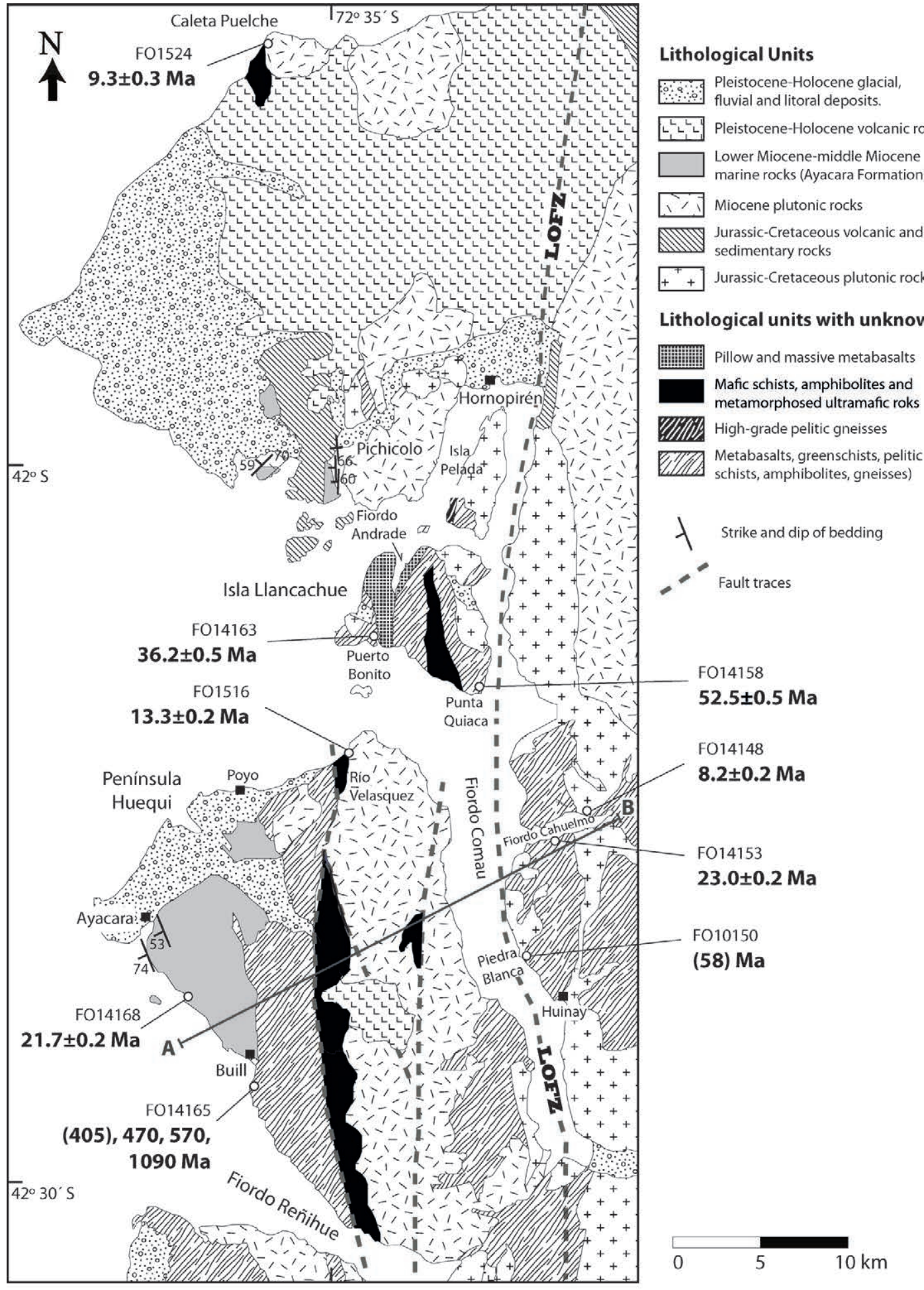

FIG. 2. Detailed sketch map of the studied area (modified from Sernageomin, 2003 and Encinas et al., 2013) indicating sample locations and the $\mathrm{U}-\mathrm{Pb}$ zircon ages obtained in this study. The location of the geological cross-section illustrated in figure 6 is shown (A-B). Liquiñe-Ofqui Fault Zone (LOFZ). 
rocks which crop out in this area have been given local names by different authors (Cembrano, 1990; Sanhueza, 1996; Crignola, 1999; Pérez, 1999). The metamorphic rock assemblages at Peninsula Huequi and the surrounding fjords to the southwest (Fiordo Reñihue) and east (Fiordo Comau) have been encompassed within a single mid PaleozoicTriassic metamorphic rock unit (MPT) defined by Encinas et al. (2014). As well as the psammopelitic component, this unit bears pillow basalts in different stages of deformation and metamorphism. In the area of Llancahue and Pelada islands (Fig. 2) there are extensive outcrops of metamorphic rocks which Cembrano (1990) mapped as the Llancahue epi-metamorphic complex, consisting of two zones of well-foliated low-grade metasedimentary and metavolcanic rocks; pillowed basalts cropping out on the west coast of Isla Llancahue in association with low-grade metasediments were also incorporated due to outcrop and structural continuity with more foliated and metamorphosed rocks to the south and east. Pankhurst et al. (1992) reported a whole-rock $\mathrm{Rb}-\mathrm{Sr}$ isochron of $292 \pm 2 \mathrm{Ma}$ for the Huinay schists on the shores of Fiordo Comau (Fig. 2), interpreted as indicating "partial isotopic homogenization during metamorphism". The outcrop includes amphibolitegrade rocks. Correlation with the Llancahue epimetamorphic complex is not well established but has been assumed, for example by Encinas et al. (2013). Outcrops along the coast ranges of south central Chile, including Isla Chiloé west of the studied area, represent a late Paleozoic accretionary complex mainly formed at the active western margin of Gondwana (e.g., Hervé, 1988), and the supposedly broadly coeval Llancahue epi-metamorphic complex and equivalents were considered to belong to that unit in most previous work in the area (e.g., Duhart, 2008 or Encinas et al., 2013).

Apart from some possibly Jurassic volcanic rocks (Pérez, 1999), Mesozoic rocks are mainly represented by plutons of the North Patagonian Batholith, which extends in time through to late Miocene (Cembrano, 1990; Sernageomin, 2003; Pankhurst et al., 1999).

Cenozoic volcanic and sedimentary rocks are represented by the marine Ayacara Formation (Levi et al., 1966; Rojas, 2003). It comprises two members: a lower one of coarse-grained sedimentary and volcaniclastic rocks, and an upper one of alternating siltstone and sandstone. Detrital zircons in the lower member have an early Miocene age peak accompanied by minor Early Cretaceous, Jurassic and Devonian peaks, in contrast with the very narrow early Miocene age range shown by zircons in the upper member (Encinas et al., 2013). These authors concluded that the Ayacara Formation was deposited during the early-middle Miocene in a deep marine forearc basin generated by extension, probably related to subduction erosion of the continental margin. Later, the basin was inverted, contemporaneously with the establishment of a transpressional regime along the LOFZ. Beck et al. (1993) and Rojas et al. (1994) used paleomagnetic studies to identify the rotation of small blocks west of the LOFZ, involving the Neogene rocks. The depositional environment of the Ayacara Formation is similar to that of the Traiguen Formation (Encinas et al., 2015), $200 \mathrm{~km}$ farther south along the Andes. Somewhat differing scenarios have been considered: an extensional basin related to the activity of the LOFZ (Herve et al., 1995), a tectonic basin formed by the action of an indentor due to increase in oblique subduction velocity (Lefort et al., 2006), or a deep intra-arc marine basin related to the general extension which affected the whole Andean orogen during late Oligocene-earliest Miocene times (Encinas et al., 2015).

\section{Methodology}

Samples were collected from localities displaying the typical outcrop characteristics of the different units, as detailed below. Petrological observations in thin sections and X-ray Diffraction (XRD) studies were made at the Laboratory for the Analysis of Solids at Universidad Andrés Bello, Santiago. Zircons were separated by standard methods of crushing, grinding, Wilfley table, magnetic and heavy liquid separation at Universidad de Chile, Santiago.

Zircon analyses were undertaken at the Research School of Earth Sciences, The Australian National University, Canberra. The grains were mounted in epoxy, polished to about half-way through the grains, and cathodoluminescence (CL) images were obtained for every zircon to select appropriate areas for analysis. U-Th- $\mathrm{Pb}$ analyses were carried out using sensitive high-resolution ion microprobes (SHRIMP II and SHRIMP RG) with procedures similar to those described by Williams (1998; and references therein). When an igneous crystallization age was required, 15 to 20 grains were analysed from each 
sample; and where possible, 60 or more grains when identification of sedimentary provenance was the purpose. Crystallization ages, where calculated, are reported here with $95 \%$ confidence limits.

\section{Ultramafic rocks}

Some of the most extensive outcrops of ultramafic rocks in the area are located in the northeastern shore of Peninsula Huequi, northeast of Poyo (Fig. 2). According to the geological map of the study zone, compiled after Cembrano (1990) and Sanhueza (1996), this area is underlain by the mid Paleozoic-Triassic metamorphic rock unit (MPT), sensu Encinas et al. (2013), which are bounded to the east by Miocene plutonic rocks. Pérez (1999) indicates a patchy distribution of ultramafic rocks, mainly in tectonic contact with sedimentary and metavolcanic rocks. A discontinuous beach section of $c a .1 \mathrm{~km}$ east of Poyo exposes ultramafic rocks, terminated to the east by a cross-cutting tonalitic dyke. Caro (2006) was able to follow the peridotite outcrops for $1.5 \mathrm{~km}$ up Río Velásquez (Fig. 2) in contact with schists of volcaniclastic protoliths. The peridotites here correspond mainly to harzburgite with coarse-grained protogranular texture composed by olivine, orthopyroxene and spinel. In thin sections, harzburgites have preferentially orientated olivine crystals some with intracrystalline deformation. Characteristic textures of serpentinite are observed as mesh texture developed from olivine, dense network of veins cutting olivines and orthopyroxenes, and as total replacement of the original rock.

Additional ultramafic rock outcrops, mainly serpentinites, have been observed at Caleta Puelche, where they are associated with foliated black phyllites and intruded by dioritic/tonalitic dykes. The remnants of harzburgites show a foliated texture characterized by visible porphyroclasts of orthopyroxene and olivine. At Pichicolo, a cataclastic Devonian tonalite is in fault contact with serpentinite (Duhart, 2008), considered to be pre-Triassic in age. Ultramafic bodies correspond to green to black fine-grained rocks which are completely serpentinized.

Preliminary results of powder XRD analyses have allowed to identify antigorite and lizardite as the main serpentine polymorphs. Fine-grained magnetite is also present in some samples. Serpentine minerals have been altered to talc and carbonates.
The rocks in the western part of Isla Llancahue are mapped by Encinas et al. (2013) as belonging to the same MPT unit, a generalization from the original definition of the Llancahue epi-metamorphic complex (Cembrano, 1990). Outcrops of somewhat foliated pillow basalts spatially associated with alternating beds of foliated black shales and sandstones are observed at Puerto Bonito (Fig. 3a). Similar foliated pillow basalts and pillow breccias crop out at Fiordo Andrade, on the northern coast of Isla Llancahue. Towards the southern end of the island the unit contains higher-grade metamorphic rocks (Cembrano, 1990), which were sampled at Punta Quiaca (Fig. 3b). Fiordo Comau has outcrops of foliated metamorphic rocks (Fig. 3c) intruded by granites that in parts, such as Fiordo Cahuelmo (Fig. 3d), constitute a stack of parallel sheets several metres thick. These rocks, also ascribed to the MPT, crop out extensively along the fjord shores; they constitute the Huinay schists of Pankhurst et al. (1992).

\section{Geochronology}

The results of the SHRIMP dating of rocks from Chiloé continental is summarized in table 1 , with fuller analytical data in the Electronic files 1 to 8 . The localities of all dated samples are shown in figure 2, with GPS readings in table 1.

\subsection{Sedimentary and metamorphic rocks}

Sample FO10150 is a biotite-hornblende gneiss with folded quartz veins, from Rocas Blancas, a locality near Huinay in Fiordo Comau considered to be late Paleozoic (Pankhurst et al., 1992). Only 25 zircon grains could be hand picked from the heavy mineral concentrate; 15 were analysed, concentrating on euhedral grains with oscillatory CL zoning interpreted as primary igneous zircon. The results (not shown in the figures) have a very dispersed range in ages from $\sim 15 \mathrm{Ma}$ to $\sim 2335 \mathrm{Ma}$, with a small grouping of three grains at about $58 \mathrm{Ma}$. Although of doubtful significance, this latter group may provide an estimate for the maximum depositional age of the sedimentary protolith; further zircon would need to be separated and analysed to investigate this contention. Alternatively, the rock could be interpreted as a Neogene orthogneiss derived from anatexis of Paleogene or younger sedimentary rocks. 

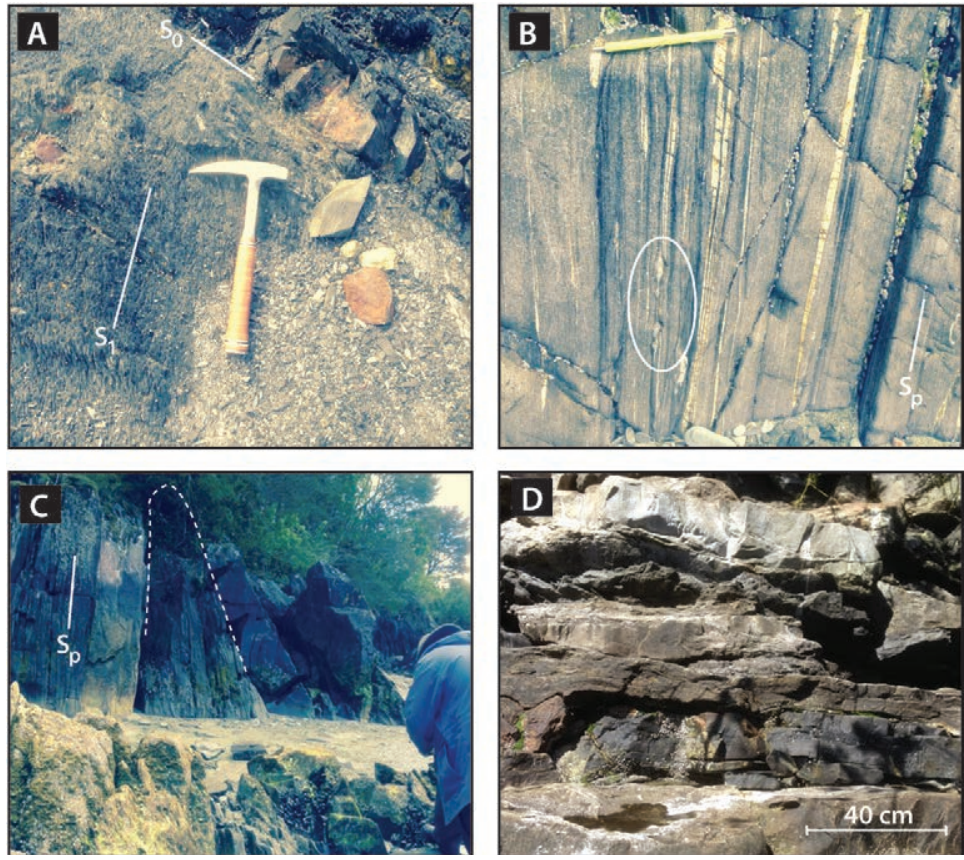

FIG. 3. Photographs of outcrops from which the analysed samples were taken. A. Cleaved siltstones and sandstone bed (FO1415) at Puerto Bonito, SW shore of Llancahue island, mapped as part of the late Paleozoic-Triassic basement by Cembrano (1990) and Encinas et al. (2013). Stratification $\left(\mathrm{S}_{0}\right)$ and main cleavage $\left(\mathrm{S}_{1}\right)$ are indicated; B. Micashists at Punta Quiaca, southern end of Isla Llancahue, mapped as higher-grade part of the Late Paleozoic-Triassic basement by Cembrano (1990). Main foliation Sp (probably $\mathrm{S}_{1}$ ), showing boudinaged veins (inside the white ellipse); C. Lllancahue epi-metamorphic complex at Punta Quiaca showing an interpreted tight fold (dashed lines) of quartzite bed with axial plane cleavage Sp (FO14158); D. Huinay schists: alternating bands of amphibolite facies metamorphic rocks and granitic bodies (FO14153) at Fiordo Cahuelmó.

TABLE 1. SUMMARY OF U-Pb SHRIMP GEOCHRONOLOGICAL DETERMINATIONS ON ZIRCONS.

\begin{tabular}{|c|c|c|c|c|c|c|c|}
\hline \multirow{2}{*}{ Sample } & \multirow{2}{*}{ Rock type } & \multirow{2}{*}{ Locality } & \multirow{2}{*}{$\begin{array}{l}\text { Geographical } \\
\text { coordinates }\end{array}$} & \multirow{2}{*}{$\begin{array}{c}\text { Crystallization } \\
\text { Age (Ma) }\end{array}$} & \multirow{2}{*}{ MSWD (n) } & \multicolumn{2}{|c|}{ Main detrital ages (Ma) } \\
\hline & & & & & & Youngest & Other peaks \\
\hline FO10150 & $\begin{array}{l}\text { Bt-Hbl } \\
\text { gneiss }\end{array}$ & $\begin{array}{l}\text { Roca } \\
\text { Blanca }\end{array}$ & $\begin{array}{l}42^{\circ} 20^{\prime} 49.9 \text { 'S } \\
72^{\circ} 26^{\prime} 59.2^{\prime \prime} \mathrm{W}\end{array}$ & - & - & 58 & (15)-2335 \\
\hline FO14165 & $\begin{array}{l}\text { meta- } \\
\text { sandstone }\end{array}$ & Buill & $\begin{array}{l}42^{\circ} 25^{\prime} 12.6 ” \mathrm{~S} \\
72^{\circ} 42^{\prime} 7.0^{\prime \prime} \mathrm{W}\end{array}$ & - & - & 405 & $\begin{array}{c}469,570,631,1100- \\
1200,1388,2643\end{array}$ \\
\hline FO14163 & $\begin{array}{l}\text { meta- } \\
\text { sandstone }\end{array}$ & $\begin{array}{l}\text { Puerto } \\
\text { Bonito }\end{array}$ & $\begin{array}{l}42^{\circ} 07^{\prime} 56.3^{\prime \prime} \mathrm{S} \\
72^{\circ} 34^{\prime} 26.2^{\prime \prime} \mathrm{W}\end{array}$ & $36.2 \pm 0.5$ & $1.3(26)$ & - & $53,115,175,350-400$ \\
\hline FO14158 & quartzite & $\begin{array}{l}\text { Punta } \\
\text { Quiaca }\end{array}$ & $\begin{array}{l}42^{\circ} 10^{\prime} 06.4 ” \mathrm{~S} \\
72^{\circ} 29^{\prime} 20.4 ” \mathrm{~W}\end{array}$ & $52.5 \pm 0.5$ & 1.7 (19) & - & - \\
\hline FO14168 & sandstone & $\mathrm{N}$ of Buill & $\begin{array}{l}42^{\circ} 21^{\prime} 30.2 ” \mathrm{~S} \\
72^{\circ} 40^{\prime} 20.4^{\prime \prime} \mathrm{W}\end{array}$ & $21.7 \pm 0.2$ & $1.4(49)$ & - & - \\
\hline FO14148 & $\begin{array}{l}\text { Bt-Hbl } \\
\text { tonalite }\end{array}$ & $\begin{array}{c}\text { Fiordo } \\
\text { Cahuelmo }\end{array}$ & $\begin{array}{l}42^{\circ} 14^{\prime} 50.0^{\prime \prime} \mathrm{S} \\
72^{\circ} 23^{\prime} 46.8^{\prime \prime} \mathrm{W}\end{array}$ & $8.2 \pm 0.2$ & $1.4(17 / 18)$ & - & - \\
\hline FO14153 & leuco-granite & $\begin{array}{c}\text { Fiordo } \\
\text { Cahuelmo }\end{array}$ & $\begin{array}{l}42^{\circ} 15^{\prime} 58.5^{\prime \prime} \mathrm{S} \\
72^{\circ} 25^{\prime} 42.2^{\prime \prime} \mathrm{W}\end{array}$ & $23.0 \pm 0.2$ & $0.6(13)$ & 32 & - \\
\hline FO1516 & Bt-tonalite & E of Polyo & $\begin{array}{l}42^{\circ} 11^{\prime} 59.3 ” \mathrm{~S} \\
72^{\circ} 36^{\prime} 07.7 ” \mathrm{~W}\end{array}$ & $13.3 \pm 0.2$ & $0.8(15)$ & - & - \\
\hline FO1524 & $\begin{array}{l}\text { Bt-Hbl } \\
\text { tonalite }\end{array}$ & $\begin{array}{l}\text { Puelche } \\
\text { ramp }\end{array}$ & $\begin{array}{l}41^{\circ} 44^{\prime} 39.0^{\prime \prime} \mathrm{S} \\
72^{\circ} 39^{\prime} 25.1{ }^{\prime \prime} \mathrm{W}\end{array}$ & $9.3 \pm 0.3$ & $0.9(16)$ & - & - \\
\hline
\end{tabular}

(n): number of areas analysed; Bt: biotite; Hbl: hornblende. 
Sample FO14165 is a $\sim 10 \mathrm{~cm}$ thick layer of fine-grained metasandstone intercalated in silicified black slates at Buill. The zircons are predominantly subequant round to subround grains and a few euhedral crystals with pyramidal terminations. The CL images reveal a variety of internal concentric zoning, both igneous and metamorphic in origin. The detrital age pattern for 70 zircons analysed (Fig. 4) has wellrepresented groupings corresponding to Ordovician ( $\sim 450-480 \mathrm{Ma})$, late Proterozoic ( $570-635 \mathrm{Ma})$, Middle Proterozoic or Grenvillian peaks around 1050-1215 Ma, a subdued 1,400 Ma clustering and an older late Archean dispersed one ( $2605-2645 \mathrm{Ma})$. At the younger end, a single grain with a ${ }^{206} \mathrm{~Pb} /{ }^{238} \mathrm{U}$ date of $\sim 14 \mathrm{Ma}$ is considered to have lost radiogenic $\mathrm{Pb}$. The grouping at $\sim 390-415 \mathrm{Ma}$ is for analyses of oscillatory zoned grains and this is interpreted as the best constraint on a maximum possible sedimentation age of around $405 \mathrm{Ma}$, consistent with the Early Devonian paleontological age of the slate boulders studied by Fortey et al. (1992).

Two samples from the epi-metamorphic complex at Isla Llancahue have surprisingly young maximum possible sedimentation ages, for a unit considered regionally to be of Late Paleozoic to Triassic age. FO14163 is a $1 \mathrm{~m}$ thick cleaved metasandstone layer with graded $\mathrm{EW} / 45 \mathrm{~N}$ bedding intercalated in predominant black pelites with slump structures, at Puerto Bonito, southwestern Isla Llancahue. $\mathrm{S} 1$ cleavage is $\mathrm{N} 55 \mathrm{~W} / 65 \mathrm{~N}$. The zircon population contains abundant euhedral crystals with pyramidal terminations and simple igneous CL zoning (oscillatory or length-parallel for prismatic grains). From the 70 grains analysed (Fig. 4) the youngest 21 have a weighted mean ${ }^{206} \mathrm{~Pb} /{ }^{238} \mathrm{U}$ age of $36.2 \pm 0.5 \mathrm{Ma}$ $(\mathrm{MSWD}=1.3)$. There are scattered Paleocene, Early Cretaceous and Early Jurassic analyses, with a significant clustering in the Devonian between $\sim 350$ and $400 \mathrm{Ma}$. FO14158 is a pale coloured quartzite in a folded packet of well-foliated micaschists and metasandstones at Punta Quiaca, southern tip of Isla Llancahue. The main foliation Sp crenulates a previous foliation, and is parallel to the lithological banding: asymmetric kinematic indicators testify to simple shear deformation. The metasandstones are boudinaged, and intrafolial isoclinal folds are present (Sp N35W/ 90). The analysed sample has feldspar phenocrysts in a fine-grained matrix, and was probably originally a tuff (metabasites are also present in the studied section). A small number of elongate prismatic zircon grains were hand-picked from the heavy mineral concentrate. They usually have broken terminations and many have axial cavities commonly seen in volcanic zircon. From the 36 grains analysed (Fig. 4), three with MiocenePliocene $\mathrm{U}-\mathrm{Pb}$ ages have high common $\mathrm{Pb}$ contents and are considered to have lost radiogenic $\mathrm{Pb}$. There is a dominant clustering around 50-60 Ma, but with an asymmetric probability density distribution. A weighted mean for 19 analyses has some scatter with $\mathrm{a}^{206} \mathrm{~Pb} /{ }^{238} \mathrm{U}$ age of $52.5 \pm 0.5 \mathrm{Ma}(\mathrm{MSWD}=1.7)$, and we interpret this sample as derived from a Paleocene tuffaceous protolith.

FO14168 is a fine-grained tuffaceous sandstone from north of Buill belonging to the Ayacara Formation. It has a homogeneous population of euhedral zircon crystals, with pyramidal terminations and prominent central cavities consistent with a volcanic paragenesis; the internal CL structure showing broad to weak zoning is also common to volcanic zircon. Forty nine of the 52 grains analysed (Fig. 4) have an early Miocene weighted mean ${ }^{206} \mathrm{~Pb} /{ }^{238} \mathrm{U}$ age of $21.7 \pm 0.2 \mathrm{Ma}(\mathrm{MSWD}=1.4)$, in accordance with the age assigned to this unit by Encinas et al. (2013).

\subsection{Igneous rock crystallization ages}

FO14148 is a coarse-grained foliated biotitehornblende tonalite from the eastern end of Fiordo Cahuelmo, with dark 3-15 cm inclusions elongated in the N30W/90 trending tectonic foliation. The zircons are generally $\sim 200-400 \mu \mathrm{m}$ long, elongate euhedral grains with bipyramidal terminations and simple igneous internal CL structures. A weighted mean ${ }^{206} \mathrm{~Pb} /{ }^{238} \mathrm{U}$ age of $8.2 \pm 0.2 \mathrm{Ma}(\mathrm{MSWD}=1.4$ ) for 17 of 18 grains analysed (Fig. 5) is considered to record igneous crystallization age.

A fine-grained, isotropic leucogranite that forms a $1 \mathrm{~m}$ thick flat-lying sheet intruding schists of the Comau metamorphic complex at the southern entrance of Estero Cahuelmo (FO14153) has a more complicated zircon population. Whereas the majority of the grains are elongate euhedral crystals with pyramidal terminations, the CL images reveal the presence of older inherited components enclosed within otherwise oscillatory-zoned zircon. The inherited zircon ages (Fig. 5) range to $\sim 1100$ Ma with a prominent, though hardly statistical cluster around $\sim 30-32$ Ma. A weighted mean for 13 oscillatory 

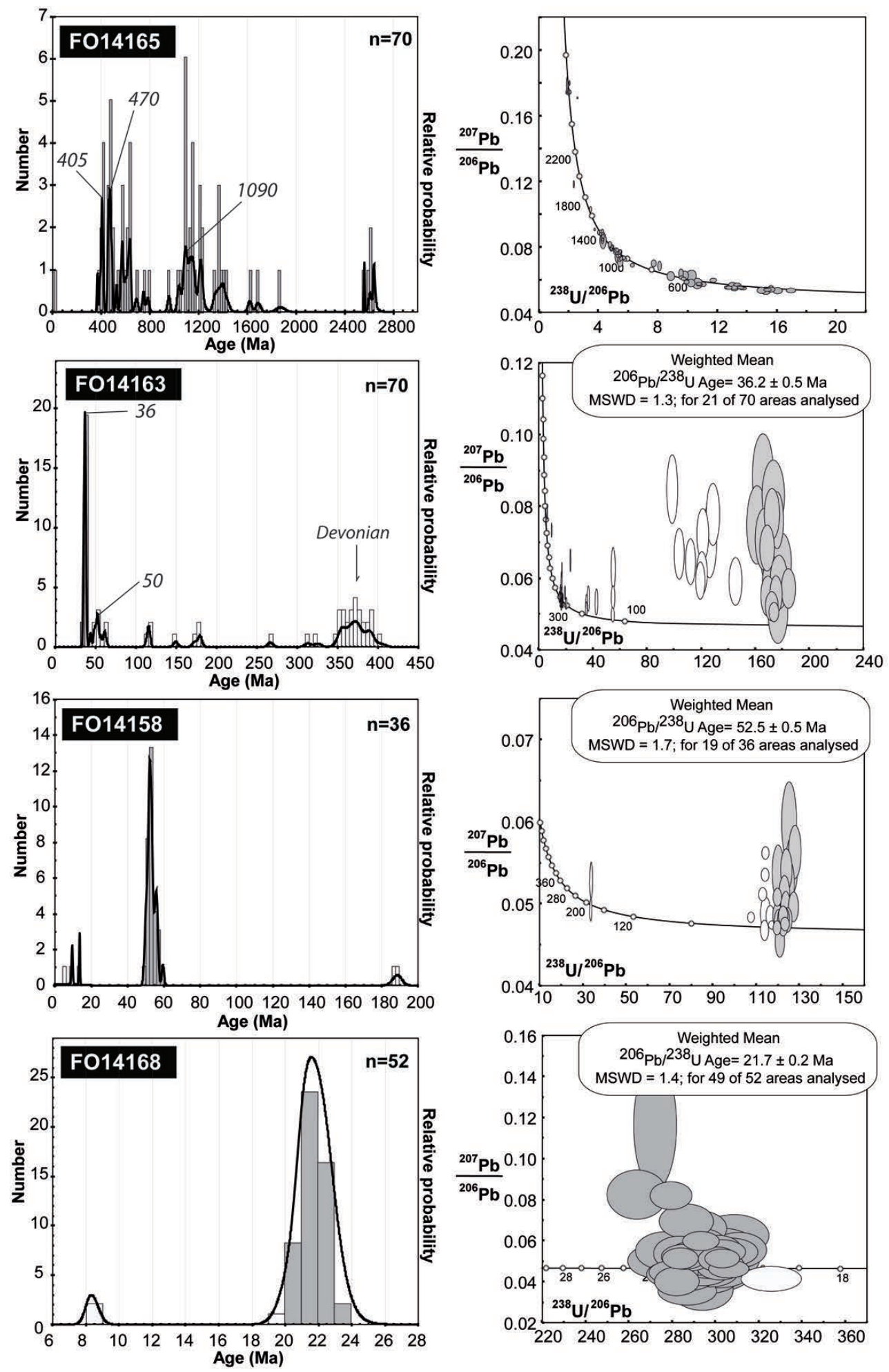

FIG. 4. U-Pb plots for zircon data from the four metasedimentary samples analysed in this study. Tera-Wasserburg plots (right-hand side) and age versus probability plots (left-hand side). 

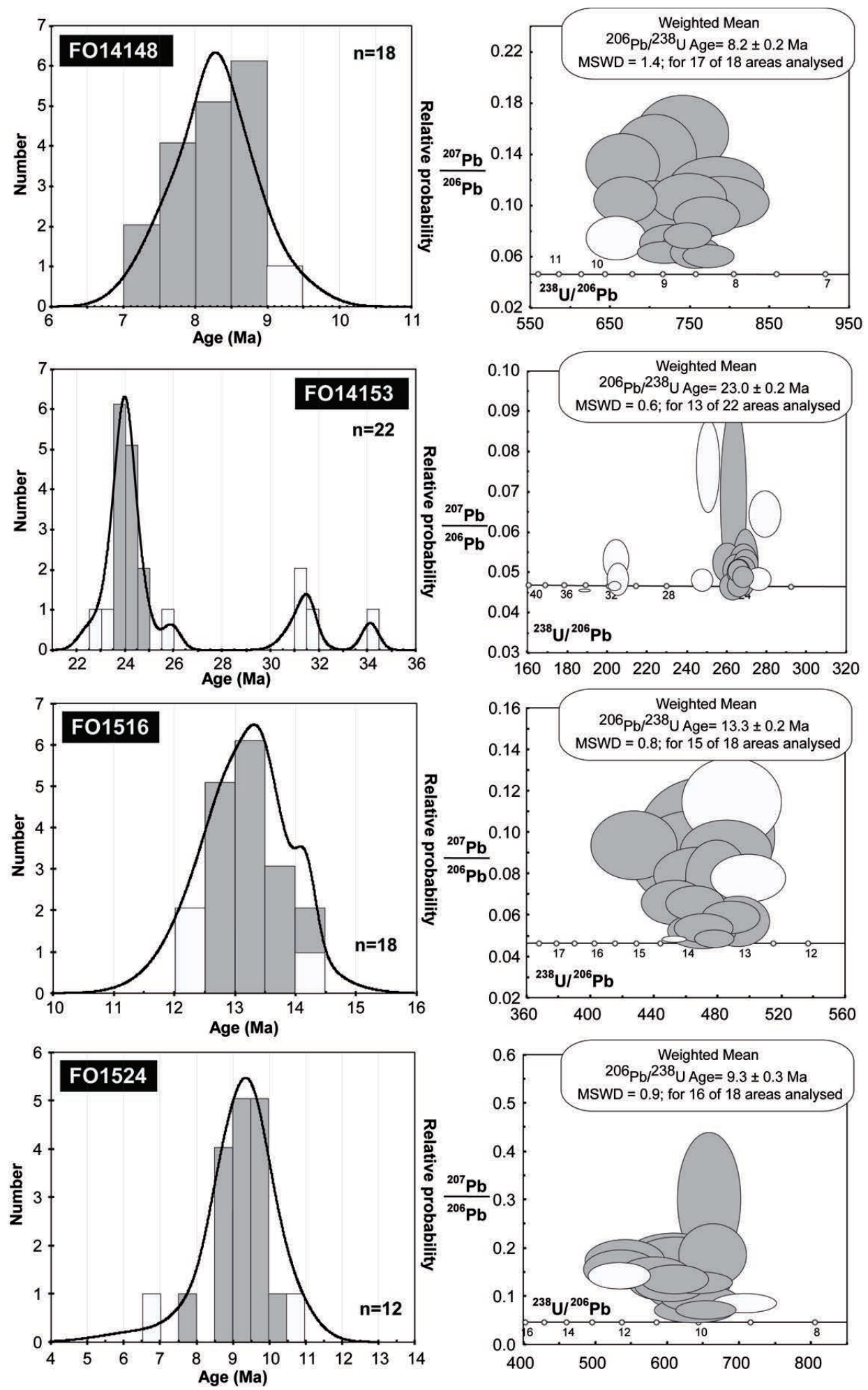

FIG. 5. U-Pb plots for zircon data from the four igneous rock samples analysed in this study. Tera-Wasserburg plots (right-hand side) and age versus probability plots (left-hand side). 
zoned igneous areas of the 22 areas analysed has a late Oligocene crystallization ${ }^{206} \mathrm{~Pb} /{ }^{238} \mathrm{U}$ age of 23.0 $\pm 0.2 \mathrm{Ma}(\mathrm{MSWD}=0.61)$.

FO1516 is a 5 m wide tabular body (N10E/70E) of biotite tonalite in the Huequi peridotite east of Poyo. It has a columnar structure, with columns perpendicular to the margins. It is a phaneritic, isotropic rock, with no inclusions. A system of quartz veins parallel to the contact does not extend into the surrounding ultramafic rock, suggesting emplacement into brittle country rock, probably at shallow depths. The zircons are dominantly elongate prismatic grains or fragments, around $100 \mu \mathrm{m}$ in length with rare coarser subhedral grains. The CL images show length-parallel zoning with some grains having subdued sector and/or oscillatory zoning. The 18 grains analysed (Fig. 5) have low to moderate $U(\sim 35-390 \mathrm{ppm})$ with a few very high $\mathrm{U}$ areas also present. A probability density plot shows an assymmetric distribution of ${ }^{206} \mathrm{~Pb} /{ }^{238} \mathrm{U}$ ages, with a main peak around $13 \mathrm{Ma}$ and a possible older component also present. Fifteen analyses forming the dominant grouping give a weighted mean ${ }^{206} \mathrm{~Pb} /{ }^{238} \mathrm{U}$ age of $13.3 \pm 0.2 \mathrm{Ma}(\mathrm{MSWD}+0.81)$, which we interpret as the igneous crystallization age.

At Caleta Puelche, a tonalite (FO1524) intrudes metamorphosed black shales that apparently overlie a serpentinite body containing some fresh peridotite portions. It is a phaneritic, isotropic rock, with inclusions of the country rock. The abundant coarsegrained ( 200-300 $\mu \mathrm{m}$ long) euhedral zircons are remarkably clear and have bipyramidal terminations. The CL images show simple igneous internal structure and 16 of the 18 grains analysed give a weighted mean ${ }^{206} \mathrm{~Pb} /{ }^{238} \mathrm{U}$ age of $9.3 \pm 0.3 \mathrm{Ma}(\mathrm{MSWD}=0.86$ ) interpreted as the igneous crystallization age (Fig. 5).

\section{Discussion}

No direct age determinations have been obtained on the crystallization or emplacement of the harzburgite or associated serpentinite. However, some of the plutonic rocks observed to intrude the ultramafic rocks and their overlying sedimentary rocks have mid-to-late Miocene ages. The contact relationships between the ultramafic rocks and the other geological units are diverse. At Pichicolo, Duhart (2008) presents evidences of a fault contact between a Devonian pluton and serpentinite. At Puelche, the northernmost outcrop of ultramafic rocks in the studied area, foliated serpentinite underlies foliated metasedimentary rocks, of unknown age. At Huequi peninsula, Caro (2006) states that the partly serpentinized peridotite is overlain by schists of volcanic protolith, which underlie black slates and are spatially associated with olivine and pyroxene ophitic gabbros, mafic gneisses and schists that contain serpentine.

The U-Pb ages of detrital zircons from the slates at Buill previously mapped as part of the mid-Paleozoic to Triassic MPT unit (Encinas et al., 2014), have yielded an Early Devonian maximum possible sedimentation age (405 Ma), concordant with the paleontological age of lithologically similar Lower Devonian fossil-bearing slate boulders assigned by Fortey et al. (1992).

The U-Pb SHRIMP zircon dating of low-grade metamorphic rocks of the Llancahue epi-metamorphic complex (Cembrano, 1990) has yielded surprising results. The maximum possible depositional ages of these rocks appears to be Late Paleocene at Roca Blanca, early Eocene at Punta Quiaca, and late Eocene at Puerto Bonito. These results rule out the previous correlation of these rocks with the Late Paleozoic accretionary complex of the Coast Ranges in Central Chile based on similar metamorphic grade and lithology (Sernageomin, 2003; Duhart, 2008; Encinas et al., 2013). Pankhurst et al. (1992) produced a whole rock Rb-Sr age of $292 \pm 2 \mathrm{Ma}$ for the Huinay schists. This "age" was interpreted as metamorphic by the authors with great caution, as several points plotted outside the errorchron and were omitted from the calculation. Late Oligocene and late Miocene plutons intruding the Huinay schists dated here do not in any way imply that the intruded rocks are Paleozoic, but neither do they prove that they are younger.

The obtained ages for rocks of the Llancahue epimetamorphic complex at Punta Quiaca and Puerto Bonito of Isla Llancahue, and for the Huinay schists at Roca Blanca, have no counterpart in previously dated geological units in the area. They are older than the late Oligocene-early Miocene Ayacara Formation, which however has a volcanoclastic lower member with an unknown base: the metasandstone from Puerto Bonito has some resemblance to the younger sample CAYA 4 of the lower member of the Ayacara Formation (Encinas et al., 2013), in sharing Cretaceous and Late Paleozoic detrital zircon age peaks, pointing to similar geological source areas. At Puerto Bonito, and at Fiordo Andrade, foliated 
pillow lavas seemingly underlie the metasedimentary rocks with a shared foliation, and thus are probably also Cenozoic, but older than the Ayacara Formation. Encinas et al. (2013) report an Eocene age for volcanic rocks at Isla Mitahue in the outcrop area of the Traiguén Formation, suggesting that deposition of volcanic rocks in the area started before the late Oligocene-early Miocene volcanic maximum.

According to Encinas et al. (2013) deposition of the Ayacara Formation is broadly contemporaneous with plate reorganization in the Pacific Ocean, which gave rise to the Nazca plate. The data presented here suggest that extensional deposition basins in this area started to develop in Paleocene and Eocene times: basaltic volcanism in this initial stage is represented by the pillow basalts at Isla Llancahue island. Paleomagnetic studies (Rojas et al., 1994) showed that counter-clockwise block rotations took place west of the LOFZ, in response to a buttressed dextral movement of the continental margin. This tectonic scenario allows the generation of extensional basins in co-existence with compressional areas, and the Ayacara Formation may have been deposited in a deep basin in which this mechanism enhanced the general early Miocene extension in the forearc.

The structure of the area was interpreted as a half-flower structure by Hervé (1994) and as a full flower structure by Encinas et al. (2013) based on the transpressional regime attending the LOFZ. The associated reverse faults might have cut the thinned continental crust of the extensional basins and thrust a slice, or slices, of the underlying lithospheric mantle now represented by the harzburgites and derived serpentinitic rocks. The association of the ultramafic rocks with gabbros and pillow basalts suggests that bi-modal volcanism occurred in these basins, as silicic volcaniclastic rocks are an important component of the deposits of the Ayacara Formation. However, the lack of a well-defined dyke swarm in this area is notable, and contrasts with what is seen in the contemporaneous Traiguén Formation $\sim 200 \mathrm{~km}$ to the south (Silva, 2003; Encinas et al., 2014).

The association of ultramafic rocks, pillow basalts and turbiditic sediments in a basin or basins aligned parallel to a main lithospheric structurethe LOFZ-can be interpreted as representing an ophiolitic suite (Pérez, 1999) developed in a suture zone. The western block, mainly comprising the Late Paleozoic accretionary prism, which might be identified as the Chiloé block of Forsythe (1982), started to rift from the South America continent in the Paleocene, reaching maximum separation during the late Oligocene-early Miocene and colliding back with the continent starting in the mid Miocene. Thus the Cenozoic evolution of this section of the North Patagonian Andes may have involved splitting off of an autochthonous terrane which soon collided back with the mother continent (Fig. 6).

\section{Conclusions}

A partially serpentinized harzburgite body crops out in the western foothills of the Main Range Andes in Continental Chiloé. Previous work was taken to indicate that this hitherto little-known body belongs to a presumed late Paleozoic volcanic and sedimentary assemblage. SHRIMP U-Pb analyses of detrital zircons from the Buill slates, which have Devonian fossils, gave a maximum deposition age of $405 \mathrm{Ma}$, consistent with that part of the unit genuinely being Paleozoic. However, such data for other rocks attributed to this unit give variable maximum possible sedimentation ages of $58 \mathrm{Ma}$, $53 \mathrm{Ma}$ and $36 \mathrm{Ma}$, clearly indicating that they were deposited during Cenozoic times. SHRIMP U-Pb ages of magmatic zircon from four cross-cutting intrusive rocks range from $24 \mathrm{Ma}$ to $8 \mathrm{Ma}$, in general agreement with this younger depositional age. A corollary is that deformational metamorphism with regional extension developed in the area during the Cenozoic, lasting until after the late Oligocene-early Miocene deposition of the Ayacara Formation.

The ultramafic rocks are interpreted as having been tectonically emplaced during the Cenozoic, in a tectonic regime associated with transpressional tectonics in the Liquiñe-Ofqui Fault Zone. This emplacement probably took place during or after mid-Miocene extension of the forearc crust, and incorporated a thin sliver of supra-subduction continental crust covering the up-thrust mantle rocks.

\section{Acknowledgements}

This study was supported by FONDECYT project 1130227. Captain C. Barrientos took us safely to the coastal exposures from Hornopirén. Dr. V. Haussermann of Huinay scientific station supported part of the initial field work in the area. Dr. G. Galaz revised initial versions of the manuscript and produced figures 1 and 2 . Revision by Dr. P. Duhart improved the text. 


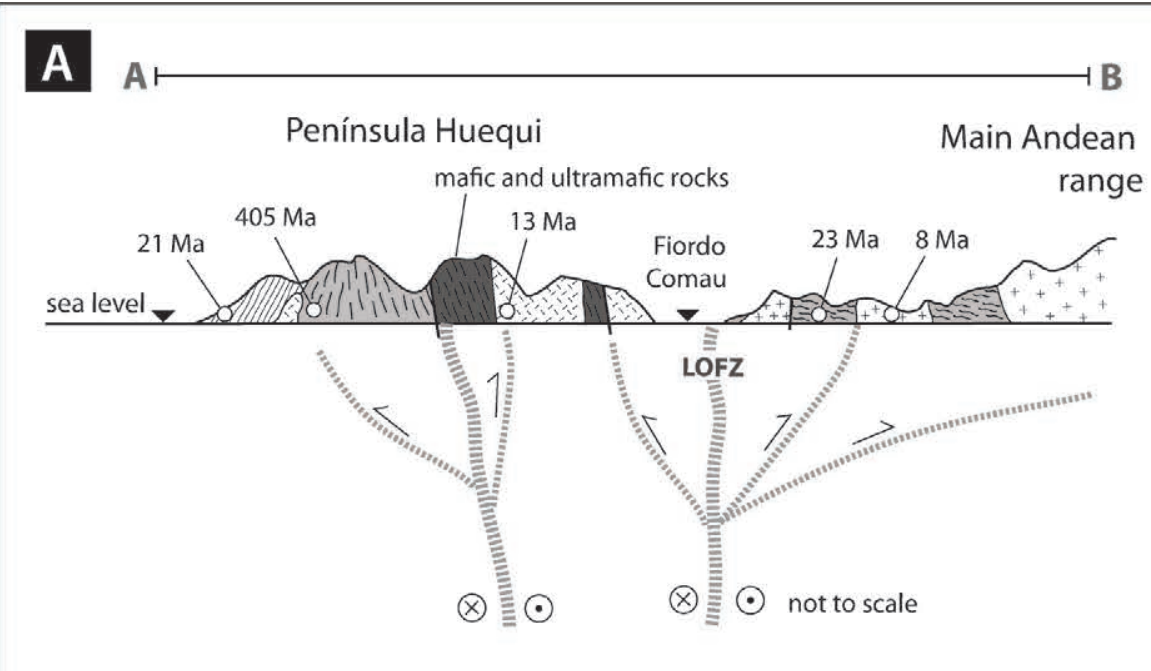

B
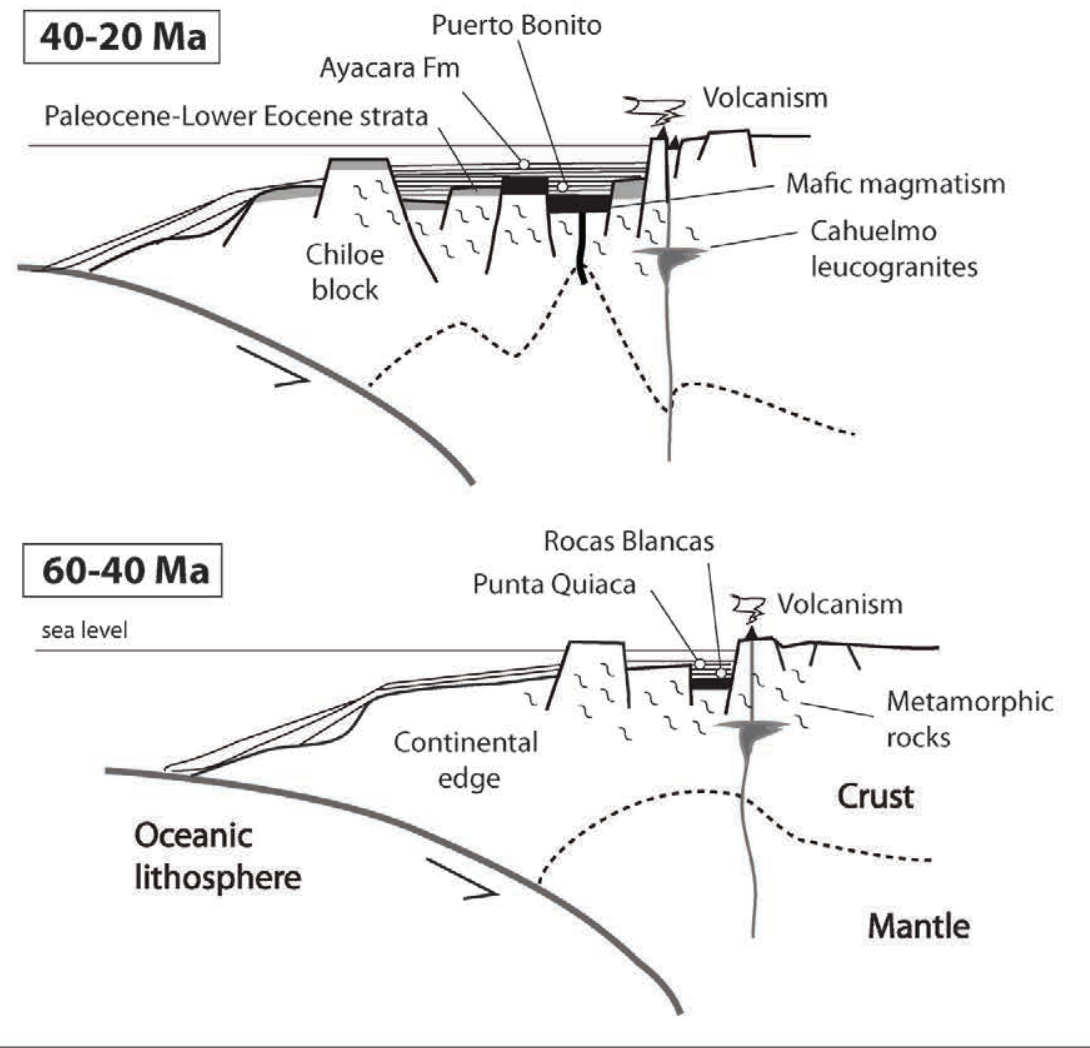

FIG. 6. A. Schematic NE-SW geological cross-section of the study area (see figure 2 for location), showing the structural relations between the different lithostratigraphic units, plutonic complexes and the Liquiñe-Ofqui Fault Zone (LOFZ). The flower structure is related to the transpressional regime attending the LOFZ since the late Miocene; B. Paleogeographic reconstructions for periods between 60-40 and 40-20 Ma, based on data and interpretations summarized in the text, indicating the generalized transtensional depositional environment and magmatism. It is highlighted the emplacement of oceanic-type mafic crust in zones of maximum extension. 


\section{References}

Adriasola, A.C.; Thomson, S.N.; Brix, M.R.; Hervé, F.; Stockhert, B. 2005. Postmagmatic cooling and late Cenozoic denudation of the North Patagonian Batholith in the Los Lagos region of Chile, $41^{\circ}-42^{\circ} 15^{\prime} \mathrm{S}$. International Journal of Earth Sciences 95: 504. doi: 10.1007/s00531-005-0027-9.

Alfaro, G. 1980. Antecedentes preliminares sobre la composición y génesis de las cromitas de La Cabaña (Cautín). Revista Geológica de Chile 11: 29-41. doi: 10.5027/andgeoV7n3-a02.

Anma, R.; Armstrong, R.; Danhara, T.; Orihashi, Y.; Iwano, H. 2006. Zircon sensitive high mass-resolution ion micro- probe $\mathrm{U}-\mathrm{Pb}$ and fission-track ages for gabbros and sheeted dykes of the Taitao ophiolite, Southern Chile, and their tectonic implications. Island Arc 15: 130-142.

Barra, F.; Rabbia, O.; Alfaro, G.; Miller, H.; Höfer, C.; Kraus, S. 1998. Serpentinitas y cromititas de La Cabaña, Cordillera de la Costa, Chile central. Revista Geológica de Chile 25: 29-44. doi: 10.5027/ andgeoV25n1-a03.

Beck, M.; Rojas, C.; Cembrano, J. 1993. On the nature of buttressing in strike slip fault systems. Geology 21: 755-758.

Cande, S.C.; Leslie, R.B. 1986. Late Cenozoic tectonics of the southern Chile trench. Journal of Geophysical Research 91B: 471-496.

Caro, R. 2006. Estudio geológico de los placeres auríferos de la Península de Huequi, Chiloé continental, X Región, Chile. Memoria de Título de Geólogo (Unpublished), Universidad de Chile, Departamento de Geología: 89 p.

Cembrano, J. 1990. Las rocas plutónicas del borde occidental del batolito norpatagónico y rocas metamórficas asociadas, Chiloé continental. Memoria de Título de Geólogo (Unpublished), Universidad de Chile, Departamento de Geología, : 64 p.

Cembrano, J.; Hervé, F.; Lavenu, A. 1996. The LiquiñeOfqui Fault Zone: a long lived intra-arc fault system in southern Chile. Tectonophysics 250: 55-66.

Crignola, P. 1999. Geología del Fiordo Reñihue y parte occidental de la Peninsula Huequi, Chiloé Continental, X Region, Chile. Memoria de Titulo de Geólogo (Unpublished), Universidad de Concepción: 115 p.

Crignola, P.; Duhart, P.; McDonough, M.; Muñoz, J. 1997. Antecedentes geoquímicos acerca del origen de los esquistos máficos y cuerpos ultramáficos en la Cordillera de la Costa, sector norte de la X Región,
Chile. In Congreso Geológico Chileno, No. 8, Actas 2: 1254-1258. Antofagasta.

Duhart, P. 2008. Processos metalogeneticos em ambientes de arco magmatico tipo andino, caso de estudo: mineralizacoes da regiao dos Andes Patagonicos setentrionais do Chile. Tesis de Doutorado (Unpublished), Universidade de Sao Paulo, Instituto de Geociencias: 215 p. Brasil.

Duhart, P.; McDonough, M.; Muñoz, J.; Martin, M.; Villeneuve, M. 2001. El Complejo Metamórfico Bahía Mansa en la cordillera de la Costa del centro-sur de Chile (39 $\left.30^{\circ}-42^{\circ} 00^{\prime} \mathrm{S}\right)$ : geocronología K-Ar, ${ }^{40} \mathrm{Ar} /{ }^{39} \mathrm{Ar}$ y U-Pb e implicancias en la evolución del margen sur-occidental de Gondwana. Revista Geológica de Chile 28: 179-208.

Encinas, A.; Zambrano, P.A.; Finger, K.L.; Valencia, V.; Buatois, L.A.; Duhart, P. 2013. Implications of Deepmarine Miocene Deposits on the Evolution of the North Patagonian Andes. Journal of Geology 121: 215-238.

Encinas, A.; Pérez, F.; Nielsen, S.N.; Finger, K.L.; Valencia, V.; Duhart, P. 2014. Geochronologic and paleontologic evidence for a Pacific-Atlantic connection during the late Oligocene-early Miocene in the Patagonian Andes (43-44 ${ }^{\circ}$ S). Journal of South American Earth Sciences 55: 1-18.

Encinas, A.; Folguera, A.; Oliveros, V.; De Girolamo, Del Mauro, L.; Tapia, F.; Riffo, R.; Hervé, F.; Finger, K.L.; Valencia, V.A.; Gianni, G.; Álvarez, O. 2015. Late Oligocene-early Miocene submarine volcanism and deep-marine sedimentation in an extensional basin of southern Chile: implications on the tectonic development of the North Patagonian Andes. Geological Society of America Bulletin 128 (5-6): 807. doi: 10.1130/B31303.1.

Forsythe, R.D. 1982. The late Paleozoic to early Mesozoic evolution of southern South America: a plate tectonic interpretation. Journal of the Geological Society 139: 671-682.

Forsythe, R.D.; Nelson, E.P. 1985. Geological manifestation of ridge collision: Evidence from the Golfo de PenasTaitao Basin, Southern Chile. Tectonics 4 (5): 477-495.

Fortey, R.; Pankhurst, R.J.; Hervé, F. 1992. Devonian trilobites at Buill, Southern Chile. Revista Geológica de Chile 19: 133-144.

Godoy, E.; Kato, T. 1990. Late Paleozoic serpentinites and mafic schists from the Coast Range accretionary complex, central Chile: their relation to aeromagnetic anomalies. Geologische Rundschau 79: 121-130.

González-Jiménez, J.M.; Barra, F.; Walker, R.J.; Reich, M.; Gervilla, F. 2014. Geodynamic implications of 
ophiolitic chromitites in the La Cabaña ultramafic bodies, Central Chile. International Geology Review 56 (12): 1466-1483. doi: 10.1080/00206814.2014.947334.

Hervé, M. 1976. Estudio Geológico de la Falla LiquiñeReloncaví en el área de Liquiñe: antecedentes de un movimiento transcurrente. In Congreso Geológico Chileno, Actas 1: B39-B56. Santiago.

Hervé, F. 1988. Late Paleozoic subduction and accretion in southern Chile. Episodes 11: 183-188.

Hervé, F. 1994. The Southern Andes between $39^{\circ}$ and $44^{\circ}$ S Latitude: the geological signature of a transpressive tectonic regime related to a magmatic arc. In Tectonics of the Southern Central Andes (Reutter, K.J.; Scheuber, E.; Wigger, P.J.; editors). Springer-Verlag: 243-248. Berlin.

Hervé, F.; Del Campo, M. 1975. Estudio petrográfico del gabro de Laguna Verde, Provincia de Valparaíso, Chile. Revista Geológica de Chile 2: 22-33. doi: 10.5027/andgeoV2n1-a03.

Hervé, F.; Araya, E.; Fuenzalida, J.L.; Solano, A. 1978. Nuevos antecedentes sobre la geología de Chiloé continental. In Congreso Geológico Argentino, No. 7, Actas 1: 629-638. Neuquén.

Hervé, F.; Pankhurst, R.J.; Drake, R.; Beck, M. 1995. Pillow metabasalts in a mid-Tertiary extensional basin adjacent to the Liquiñe-Ofqui fault zone: the Isla Magdalena area, Aysén, Chile. Journal of South American Earth Sciences 8: 33-46.

Hernández, L. 2006. Rocas máficas y ultramáficas en Laguna Verde, Chile central. Memoria Título de Geólogo (Unpublished), Universidad de Chile, Departamento de Geología: 132 p.

Heusser, C.J. 1990. Chilotan piedmont glacier in the southern Andes during the last glacial maximum. Revista Geologica de Chile 17 (1): 3-18. doi: 10.5027/ andgeoV17n1-a01.

Höfer, C.; Kraus, S.; Miller, H.; Alfaro, G.; Barra, F. 2001. Chromite-bearing serpentinite bodies within an arc-backarc metamorphic complex near La Cabaña, south Chilean Coastal Cordillera. Journal of South American Earth Sciences 14: 113-126. doi:10.1016/ S0895-9811(01)00011-6.

Lefort, J.P.; Aifa, T.; Hervé, F. 2006. Structural and AMS study of a Miocene dyke swarm located above the Patagonian subduction. In Dyke Swarms- Time Markers of Crustal Evolution (Hanski, E; Mertanen, S.; Ramö, T.; Vuollo, J.; editors), Taylor and Francis Group: 225-241. London.

Levi, B.; Aguilar, A.; Fuenzalida, R. 1966. Reconocimiento geológico en las provincias de Llanquihue y Chiloé. Instituto de Investigaciones Geológicas, Boletin 19: 45 p. Santiago.
Ojeda, J.M. 1976. Estudio petrológico y estructural del basamento metamórfico y de la serpentinita de Morro Bonifacio, provincia de Valdivia, Décima Región. Memoria de Título (Unpublished), Universidad de Chile, Departamento de Geología: 94 p.

Pankhurst, R.J.; Hervé, F.; Rojas, L.; Cembrano, J. 1992. Magmatism and Tectonics in continental Chiloé, Chile (42-42 $\left.{ }^{\circ} 30^{\prime}\right)$. Tectonophysics 205: 283-294.

Pankhurst, R.J.; Weaver, S.D.; Hervé, F.; Larrondo, P.; 1999. Mesozoic-Cenozoic evolution of the North Patagonian Batholith in Aysen, Southern Chile. Journal of the Geological Society 156: 673-694. London.

Pérez, Y. 1999. Geología de la region oriental de la Peninsula Huequi y zonas costeras del Fiordo Comau (4200’-42³0’S), Chiloé Continental, Provincia de Palena, X Región. Memoria de Título de Geólogo (Unpublished), Universidad de Concepción: $172 \mathrm{p}$.

Rojas, C. 2003. Estratigrafía, facies y paleomagnetismo de la Formación Ayacara, Provincia de Palena. Memoria Título de Geólogo (Unpublished), Universidad de Chile, Departamento de Geología: 84 p.

Rojas, C.; Beck, M.; Jr., Burmester, R.F.; Cembrano, J.; Hervé, F. 1994. Paleomagnetism of the Mid Tertiary Ayacara Formation, southern Chile: counterclockwise rotation in a dextral shear zone. Journal of South American Earth Sciences 7: 45-56.

Sanhueza, A. 1996. El Complejo Acrecionario y la Zona de Falla Liquiñe-Ofqui en los fiordos Reñihué y Comau ( $\left.42^{\circ}-43^{\circ} \mathrm{S}\right)$, Chiloé Continental. Memoria de Título de Geólogo y Grado de Magíster en Geología (Unpublished), Universidad de Chile, Departamento de Geología: 93 p.

Schilling, M.; Carlson, R.W.; Vieira, R.; Dantas, C.; Bertotto, G.W.; Koester, E. 2008. Re-Os isotope constraints on subcontinental lithospheric mantle evolution of southern South America Earth and Planetary Science Letters 268: 89-101.

SERNAGEOMIN (Servicio Nacional de Geología y Minería) 2003. Mapa Geológico de Chile, Versión Digital: Sernageomin Publicación Geológica Digital 4, CD- ROM, version 1.0, scale 1:1.000.000. Chile.

Silva, C. 2003. Ambiente geotectónico de erupción y metamorfismo de metabasaltos almohadillados, Andes Norpatagónico $\left(42^{\circ} \mathrm{S}-46^{\circ} \mathrm{S}\right)$, Chile. Memoria de Título de Geólogo y Grado de Magíster en Geología (Unpublished), Universidad de Chile, Departamento de Geología.

Vergara, L. 1970. Prospección de yacimientos de cromo y hierro en La Cabaña, Cautín. Memoria de Título 
(Unpublished), Universidad de Chile, Departamento de Geología: 96 p.

Williams, I.S. 1998. U-Th-Pb geochronology by ion microprobe. In Applications of Microanalytical
Techniques to Understanding Mineralizing Processes (McKibben, M.A.; Shanks III, W.C.; Ridley, W.I.; editors). Reviews of Economic Geology 7: $1-35$.

Manuscript received: March 16, 2016; revised/accepted: October 24, 2016; available online: October 27, 2016. 